Article History:

Submitted:

28 October 2020

Reviewed:

30 October 2020

Edited:

18 November 2020

16 January 2021

30 January 2021

Accepted:

1 February 2021

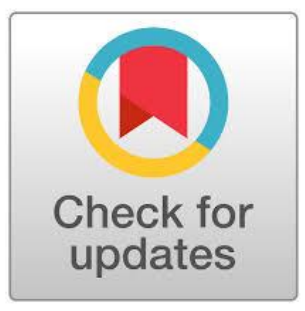

\section{Autonomous Learning during COVID-19 Pandemic: Students' Objectives and Preferences}

\author{
Teguh Ariebowo
}

Sekolah Tinggi Teknologi Kedirgantaraan, Indonesia

teguh.arie@sttkd.ac.id

DOI: https://doi.org/10.18196/ftl.v6i1.10079

\begin{abstract}
Students' voices remain one of the essential sources to evaluate and develop learning materials in which students as the center. This study attempts to evaluate the current English teaching and learning process in a school of aerospace technology. The researcher felt the urge to evaluate it since the teaching and learning process suddenly turned the direction into online learning due to the COVID-19 pandemic globally. Specifically, this study explored the students' objectives and preferences in learning English during the current situation. Initially, the researcher asked students in one of his classes randomly to be interviewed as the study's preliminary data. A questionnaire was developed from the interview to survey all students of his classes, with 166 students in total. Besides interviews and questionnaires, the data were also collected from the documentation owned by the academic affairs. From the data, it was found that students were basically aware of their learning objectives that corresponded positively to the curriculum developer's objectives. Their preferences in online learning showed how autonomous they were as English learners. However, some findings from the documentation indicated criticism to the teachers that revealed another learner autonomy level.
\end{abstract}

Keywords: needs analysis; online learning; autonomous learning 


\section{Introduction}

The first case of COVID-19 was found in Wuhan, China, in December 2019. A report issued by WHO stated that the Chinese government underwent a retrospective investigation and found that the onset symptoms have occurred since early December 2019 (WHOb, 2020). The novel coronavirus happens to be human to human infection. It was mentioned that the rapid spread of coronavirus due to human droplets as the mode of transmission (WHOa, 2020). WHO clarified that droplet transmission occurs when a person stays close (within 1 meter) with someone with symptoms such as coughing and sneezing. Therefore, his/her mouth, nose, and eyes are at risk of being exposed to potentially infective droplets from the respiratory system (WHOa, 2020). Airborne transmission is also predicted to be one of the transmission modes. However, it was clearly mentioned that it may occur in specific circumstances and procedures, where aerosols are generated and performed.

Meanwhile, Indonesia's first COVID-19 case was only found on $2^{\text {nd }}$ March 2020, two months after the world's first case. From January to March 2020, several national regulations were produced by the governments at different levels, from the president to ministerial (Djalante, et al., 2020). The President of Indonesia had only taken a real action of law in one month and eleven days after the first case by issuing Presidential Decree Number 9 of 2020 entitled Task Force for Rapid Response to COVID-19. The critical decision related to fiscal response precisely was not coming from the president. However, the first fiscal regulation in response to COVID19 came from the Ministry of Finance through the Decision of Minister of Finance 6/KM.7/2020. The President of Indonesia only issued the significant decision related to the national fiscal allocation in response to the rapid spread of COVID-19 on the Government Regulation in Lieu of Law Number 1/2020 entitled National Budgeting Policy and the Stability of Budgeting System for COVID-19 Pandemic Disaster and/or Managing Threats for National Economy and/or the Stability Budgeting System (Djalante, et al., 2020).

In response to the COVID-19 pandemic, the Ministry of Education and Culture closed 530,000 schools after the first local case was found in March 2020. Hence, the government developed a learning from home guidance based on global guidelines and established distance learning alternatives through online, TV, and print materials on its Minister of Education Circular Letter Number 15 of 2020. Distance learning is understood as the learning process 
where the learners may not be physically present at the school (Sadeghi, 2019). As a matter of fact, the majority of the learning medium today is the internet network, which is commonly called online learning. In fact, most schools in Indonesia have not fully implemented online learning based on the schools' condition since many students in Indonesia's rural or remote areas cannot access the internet.

Despite the fact that students living in this era are part of Generation- $Z$ and known as a digital native, Indonesia's teaching and learning process cultivate problems and complaints from students, teachers, and parents. Moreover, Indonesia's education system has now adopted the $21^{\text {st }}$ Century Learning concept, where schools and universities should not wait for such a pandemic happening today to implement online learning. However, it is contrary to the fact that this current status provides significant problems in implementing online learning (Churiyah, Sholikhan, Filianti, \& Sakdiyyah, 2020). Teachers find it difficult to decide the suitable tools to practice distance learning (Indonesia Inside, 2020). It reflects the real condition of the Indonesia Education System.

The researcher captured some articles discussing readiness and questioning whether or not students, teachers, or schools and universities ready to conduct online learning (Anza, Luthfi, \& Saragih, 2019; Churiyah et al., 2020; \& Waryanto \& Stayningrum, 2014). In this COVID-19 pandemic situation, being ready to conduct online learning is an absolute fact. The most important thing to prepare is adapting and dealing with the barriers and then finding the solution.

Considering the situation mentioned above, the English teachers in a college called Sekolah Tinggi Teknologi Kedirtagantaraan (College of Aerospace Technology) conducted an evaluation of the English program and its teaching and learning materials. According to Brown (1995), teachers or materials developers should start the process with need analysis in evaluating teaching and learning materials. Furthermore, Richards (2001) mentioned that a sound educational program should be based on a comprehensive analysis of learners' needs. Hence, to execute the evaluation program, a need analysis was conducted by exploring the students' needs, particularly in terms of learning objectives and preferences in two research questions: (1) What are the students' objectives in learning English? (2) What are their preferences in learning English in the COVID-19 pandemic situation? 


\section{Literature Review}

\section{Needs Analysis}

Richards (2001) pointed out that needs analysis is a procedure to collect information about learners' needs. The gathered information is then analyzed to find out language skills a learner needs, to identify a change of direction of the curriculum, to identify the gap between what the students learned and what the students really need, or simply to collect information regarding difficulties faced by the learners especially in the learning process. Shortly, a need analysis is needed when it is within the purposes desired by the material developers.

Several procedures can be employed to administer a need analysis such as questionnaire, self-ratings, interviews, meetings or focused group discussion, observation, learner language samples, task analysis, case study, or even analysis of available information (Richards, 2001). The researcher could not find any article or book mentioning that a particular method best suits need analysis. A need analysis can be administered using only one method or multiple ones. For instance, Danise Lawson's needs assessment explained in Graves (2000) mentioned seven procedures. They comprised asking the students to write feedback about his course, write their English experience, write their personal goals and objectives, fill out the questionnaire, write anonymous feedback cards, be involved in in-class discussions, and participate in student-teacher conferences. Despite the number of procedure a researcher takes to administer a need analysis, one thing for sure is that a researcher must go through the need analysis cycle: 1) decide what information to gather and why, 2) decide when, from whom, and who gather it, 3) gather information, 4) interpret it, 5) act on it, and 6) evaluate the effect of the action (Graves, 2000; Hutchinson \& Waters, 1984; Nation \& Macalister, 2010; and Richards, 2001).

Furthermore, there are types of information commonly gathered from learners in a need analysis to make the interpretation and action more precise and close to the learners' need, lack, and want (Nation \& Macalister, 2010). The information consists of 1) who the learners are, 2) the learners' language proficiency levels, 3) the learners' intercultural competence levels, 4) their interests, 5) their learning preferences, 6) their attitudes, 7) the learners' goals, 8) the target context such as situation, roles, topics, and content, 9) type of communication skills they will need and tasks they will perform, and 10) language modalities they will use (Graves, 2000). 
Hence, in this study, information gathered from the need analysis would be utilized to provide a basis for evaluating the existing English program for Air Transport Management students. Regarding the type of information gathered, procedure, and who administered this need analysis, the researcher explained them in the methodology section.

\section{Learner Autonomy Objectives and Preferences}

For more than 30 years, autonomous learning has become a popular topic to discuss in foreign language (FL) teaching (Borg \& Al-Busaidi, 2012). It was started by Holec (1981) whose definition is later widely used. He claimed that an autonomous language learner could control his learning situation by setting his learning objectives, constructing the content to be learned and its progress, choosing the method and techniques to be applied, monitoring the learning process, and determining the evaluation. Little (1991) proposed a little bit different definition, although it brings a similar sense implicitly. It was stated that autonomy by itself is a capacity to detach, make a critical reflection and decisions, and take independent action.

The discussion on learner autonomy's definition continues and extends to the notion of level and version of autonomy. Nunan (as cited in Chitashvili, 2007) introduced the five levels of autonomy that refer to the learner actions comprising 'awareness', 'involvement', 'intervention', 'creation' and 'transcendence' (see Table 1). He also involved two dimensions in getting the full depiction of learner autonomy, namely 'content' and 'process'. For instance, at the lowest level of learner autonomy, learners are aware of pedagogical goals. Therefore, most learners at this level know what materials they are using. Consequently, they can select their learning strategy since learners identify the implication of the tasks contained in the materials. 
Journal of Foreign Language Teaching and Learning

Volume 6, No. 1, January 2021

Available online at: https://journal.umy.ac.id/index.php/FTL/issue/view/720

e-ISSN: 2580-2070, p-ISSN: $2527-7650$

Table 1. David Nunan's Autonomous Learning Level as cited in Chitashvili (2007)

\begin{tabular}{|c|c|c|c|}
\hline Level & Learner Action & Content & Process \\
\hline 1 & Awareness & $\begin{array}{l}\text { Students are aware of their learning } \\
\text { objectives and the content they are } \\
\text { learning. }\end{array}$ & $\begin{array}{l}\text { Students can identify } \\
\text { the learning strategy } \\
\text { applied and identify } \\
\text { their preferred } \\
\text { learning styles/ } \\
\text { strategies. }\end{array}$ \\
\hline 2 & Involvement & $\begin{array}{l}\text { Students are involved in choosing their } \\
\text { objectives from a range of options } \\
\text { offered. }\end{array}$ & $\begin{array}{l}\text { Students select } \\
\text { choices from the } \\
\text { options. }\end{array}$ \\
\hline 3 & Intervention & $\begin{array}{l}\text { Besides being involved in selecting } \\
\text { choices, students are also invited to } \\
\text { modify and adapt the learning goals and } \\
\text { the content. }\end{array}$ & $\begin{array}{l}\text { Students modify and } \\
\text { adapt the tasks. }\end{array}$ \\
\hline 4 & Creation & $\begin{array}{l}\text { Students make initiatives to create their } \\
\text { learning objectives. }\end{array}$ & $\begin{array}{l}\text { Students can create } \\
\text { tasks that suit their } \\
\text { learning objectives. }\end{array}$ \\
\hline 5 & Transcendence & $\begin{array}{l}\text { Students can go beyond the classroom } \\
\text { and connect the content of researchers, } \\
\text { the classroom, and the world beyond. }\end{array}$ & $\begin{array}{lr}\text { Students } & \text { become } \\
\text { teachers } & \text { and } \\
\text { researchers. } & \end{array}$ \\
\hline
\end{tabular}

In the next levels of involvement, intervention, creation, and transcendence, they can select their goals and content from various options, modify and adapt, create, and make links between them, respectively. Conspicuously, Nunan remained consistent dealing with the learner autonomy level around the language learning framework. Therefore, in this study, the researcher employed the learner autonomy level by Nunan (as cited in Chitashvili, 2007) to analyze the students' autonomy levels.

Research conducted by Cirocki, Anam, and Retnaningdyah (2019) uncovered that learners in Indonesia had low motivation in learning English, which was closely related to learning autonomy. The study also found that learners were not quite ready to be autonomous learners; it was proven by their survey result on learners' dependency on teachers exhibiting a high score. Resonate to Cirocki et al. (2019), research conducted by Lengkanawati (2017) also mentioned that teachers in Indonesia thought that Indonesian learners very much depended on their teachers. It is also inferred in this study that autonomy was not yet common among Indonesian students. 
Journal of Foreign Language Teaching and Learning

Volume 6, No. 1, January 2021

Available online at: https://journal.umy.ac.id/index.php/FTL/issue/view/720

e-ISSN: 2580-2070, p-ISSN: 2527-7650

\section{Methodology}

As mentioned in the literature review that no single absolute procedure that suits any particular need analysis process, this needs analysis was administered using three procedures, consisting of a semi-guided interview, Likert scale and open-ended questionnaire, and analysis of available information or usually called documentation.

First of all, the semi-guided interview was employed to gather information from the 20 students of the fifth semester randomly selected. The questions in the interview guideline were derived from the framework proposed by Graves (2000). Not all type of information proposed by Grave was used to make questions in the interview guideline since some of the information has been existing or not applicable, such as who the learners were, the learners' intercultural competence levels, and their interests and attitudes. The researcher has provided the interview guideline in Appendix 1. During the interview, the researcher took notes to record all the answers. Table 2 displays information captured by the researcher in the preliminary study. 
Journal of Foreign Language Teaching and Learning

Volume 6, No. 1, January 2021

Available online at: https://journal.umy.ac.id/index.php/FTL/issue/view/720

e-ISSN: 2580-2070, p-ISSN: $2527-7650$

Table. 2. The Results of Preliminary Research

\begin{tabular}{ll}
\hline Learning objectives & $\begin{array}{l}\text { Being able to speak English fluently without bothering tenses as } \\
\text { long as it is understandable }\end{array}$ \\
\hline Building the vocabulary related to Air Transport Management \\
\cline { 2 - 2 } Improving listening skill \\
\hline Improving reading skill \\
\hline Improving writing skill \\
\hline Problems faced by Airline companies \\
\hline Issues related to aviation safety \\
\hline Issues related to aviation security \\
\hline Human resource management \\
\hline Marketing communication \\
\hline Giving information \\
\hline Giving instruction \\
\hline Delivering presentation \\
\hline Responding complaints \\
\hline Giving opinion \\
\hline Skills
\end{tabular}

Second of all, after having the above results, the researcher used the interview result to generate a questionnaire spread to 166 participants from all students in the fifth group. One of the researcher's considerations to conduct the interview prior to the questionnaire was Richards' (2001) statement that it is useful to carry out some interviews before designing the questionnaire to the appropriate topics and issues. The questionnaire is provided in Appendix 2. Since this study used a survey as the approach, the descriptive quantitative model was selected to analyze the data. To get the triangulation data, the researcher gave a set of open-ended questions to 40 students randomly selected. The open-ended questions were sent via WhatsApp, and the students made their answered recorded and sent back. The open-ended questions were mostly asked about their online learning experiences related to their learning goals and learning preferences, such as content topic, text type, and speaking skills. 
Last but not least, the Office of Academic Affairs of this aviation college had surveyed the online learning process during the COVID-19 pandemic. To get ample data related to the learning preferences, the researcher decided to use some of the survey results from the Office of Academic Affairs.

\section{Context}

Before embarking to the discussion of each result of the survey, a brief overview of the context and curriculum is explained. Six majors comprising bachelor degree, diploma and diploma certificate are available in this aviation college. This study was conducted in English class taught in Air Transport Management (ATM) major. The ATM has the most students amongst the majors. As in other universities, English becomes one of mandatory subjects in all majors. However, each major has its own authority to develop the curriculum including English. In ATM, English is taught in six semesters. Due to the limited classroom, the English subject in this major was required to run the class with 40 students in one group. To some extent, the number of students in one class has been a never-ending problem faced by the English teachers in Indonesia including, in this school. Numbers of studies discussing class size's impact on students' achievement have been conducted for a couple of decades. It led to the policy of decreasing the number of students in one class in many countries, such as the United States of America, Japan, China, and European countries (Koc \& Celik, 2014). This policy's belief is common to support that smaller classes positively impact the children's academic achievement. Without any doubt, the learning situation should be able to establish a positive and encouraging learning atmosphere. In achieving them, teachers must be aware that there are two kinds of motivation standing in a learner-intrinsic and extrinsic motivation (Harmer, 2007). The classroom setting may become one of the extrinsic motivations. Students in this aviation college mostly agreed that the class size was much bigger than they expected. They admitted that such a situation, to some extent, affected their motivation to learn English. In one of the answers in the open-ended questions survey with students, it was said that:

"When I first study English in this college, I thought that the English class was not this big. I thought I would be only a maximum of 20 students in one class. It finds me hard to express and practice my English since the teacher has to accommodate each learner who wants to proact their speaking. It is tough since the number of the meeting is very limited.” 
The above-situation was worsened by the minimal number of face-to-face meeting classes as one of the online learning consequences due to the COVID-19 pandemic situation. Due to limited internet access that students experienced, teachers decided to limit the synchronous online meeting based on the survey result done by the Office of Academic Affairs.

Concerning the curriculum, students were given the basic General English in semester one to three. Teachers admitted that there was no research prior to the process of developing its curriculum. Teachers involved in developing the curriculum believed that most freshmen students' English proficiency levels were low when they first entered the school. The teachers' belief was confirmed by the survey result of students' perception towards their English proficiency level, as shown in Table 3.

\section{Findings and Discussion}

\section{English Proficiency Level}

Table 3 tells how most students perceived themselves as beginner English learners. When they first entered the college, $74 \%$ perceived that they were at beginner English level. It was divided into two sub-levels, namely A1 and A2, 49\% and 25\% respectively. 10\% of the students believed that their English entry level was B1, and only 9\% thought they were in the upper intermediate level. Very few, around 7\%, were confident enough to admit that they belonged to the advanced level.

Table 3. Students' Perceptions on Their English Proficiency Levels

\begin{tabular}{|c|c|c|c|}
\hline & $\begin{array}{c}\text { CEFR English } \\
\text { Proficiency Level }\end{array}$ & Entry Level (\%) & Current Level (\%) \\
\hline \multirow[t]{2}{*}{ Beginner } & A1 & 25 & 11 \\
\hline & A2 & 49 & 27 \\
\hline \multirow[t]{2}{*}{ Intermediate } & B1 & 10 & 34 \\
\hline & B2 & 9 & 19 \\
\hline \multirow[t]{2}{*}{ Advanced } & $\mathrm{C} 1$ & 7 & 9 \\
\hline & $\mathrm{C} 2$ & - & - \\
\hline
\end{tabular}


At the students' current levels in their fifth semester of study, overall, students perceived that they improved their English proficiency level. Only 38\% remained perceiving themselves at the beginner level, with $11 \%$ in A1 and $27 \%$ in A2. 34\% of them proudly said that they currently belonged to the intermediate level. 10\% more students than at the entry-level believed that they were now in upper-intermediate level. However, none of the students believed that they were at the C2 level as they did not at their entry-level.

The data in Table 3 showing how students perceived themselves related to English proficiency is, in fact, in line with the quantitative data presented by Nurweni and Read (1999), saying that most first-year students of some universities in Indonesia, on average, knew not even close to 3,000 words. As referenced by Nation (2006) and Schmitt (2014) students believed to be able to read unbridged general text with adequate understanding. In fact, those students' vocabulary knowledge was only at 1226 English words, which was considered as severely inadequate (Nation, 2006; Schmitt, 2014). This fact resonates with the data revealed by (Milton \& Alexiou, 2010) that the English vocabulary size for level A1 CEFR was less than 1,500.

\section{Length of English Learning Experience}

The truth found in discussion point 2 is more inconvenient when knowing that students in Indonesia mostly have experienced learning English in school for at least nine years. In Indonesia's educational curriculum, English subject is not taught until the students are in grade seven although, in some elementary schools, especially the private ones, English subject has been provided for students from the first to sixth grade (see Table 4). However, in this research, most students experienced learning English for more than ten years in school. When the learning experience is understood as durational units that can be recalled (Vedeler, 2015), how long a learner studies English does not correspond exponentially to his/her English proficiency. Sadly, although Indonesian students experience many years of English instruction in formal education, the outcome seems far from satisfying (Lie, 2009). 
Table 4. Students' Experiences in Learning English

\begin{tabular}{cc}
\hline $\begin{array}{c}\text { English Learning Experiences } \\
\text { (years) }\end{array}$ & $\begin{array}{c}\text { Number of students } \\
(\%)\end{array}$ \\
\hline $3-6$ & 7.83 \\
\hline $7-9$ & 18.07 \\
\hline $10-12$ & 27.10 \\
\hline 12 & 46.99
\end{tabular}

Knowing the fact that many students were still in the low level of English proficiency, the English curriculum designers in most universities in Indonesia decided to generally mandate the freshmen to study English from the very beginning level. In other words, the university authority set them to restart learning English. Consequently, the first and second semesters allowed students to learn basic English through General English (Widodo, 2015). Students learned more complex topics in the third and fourth semesters, such as daily conversation in a work setting and considering cross-cultural understanding. A very interesting finding was revealed from the first question of the open-ended written interview to 50 respondents. Most of them answered that they studied English because they had to fulfill the curriculum's requirement. In this case, the author could infer from the answers that the motivation owned is only to have a good grade. High achiever students admitted that they came to the class punctually and did the best at any quiz because they wanted the best grade in every course. Meanwhile, lower achiever students tended to fulfill the minimum requirement mandated by the school merely.

\section{Learning Objectives}

A follow-up question was raised to dig into the real objective of the students to study English. The respondents were in the $6^{\text {th }}$ semester when being interviewed. Most students claimed that studying English in college prepared them to face the working environment that required them to speak English daily. They were entirely aware that working in the field of air transport management obliged them to be capable of conversing in English. Besides working in airports or airlines, some students planned to pursue a master's degree in air transport management, where English was mostly required. In Table 5, it figures out what students wanted to pursue in learning English. 
Table 5. Students' Learning Objectives

\begin{tabular}{lc}
\hline \multicolumn{1}{c}{ Learning objective } & Percentage \\
\hline To be fluent, whether they are grammatically correct & 86.74 \\
\hline Improving listening skill & 77.71 \\
\hline Building up the vocabulary size in the area of Air Transport Management & 59.63 \\
\hline Improving reading skill & 43.97 \\
\hline
\end{tabular}

In this study, the students were required to choose two out of four learning objectives. From 166 respondents, $86.74 \%$ chose to be fluent in English without bothering grammatical aspects. They wanted to be able to strike on a conversation in English without hesitation and worry about their grammar. They admitted that they did not really bother about the grammatical aspect as far as the audience understood what they conveyed in the conversation. In the second place, about $77.71 \%$ of the students seemed to improve their listening skills as it is vital in a conversation. This empirical fact was very much related to what Krashen (1982) has implied that speaking is the production skill of the listening skill. To be able to speak a language, learners must improve their listening. In the third and fourth place were building up the vocabulary size and improving reading skills, respectively. It implied that learners remained seeing the speaking skill as the primary indicator of language proficiency.

\section{Learning Preferences}

Speaking skills became the most popular language skill among the learners. Concerning that, this study also explored the learner's preferences in learning speaking. The researcher picked the five most mentioned language functions that could be used in any professional setting. The five language functions were gathered from the preliminary research, comprising responding to a complaint, giving information, instruction, opinion, and delivering a presentation. See Table 6. 
Journal of Foreign Language Teaching and Learning

Volume 6, No. 1, January 2021

Available online at: https://journal.umy.ac.id/index.php/FTL/issue/view/720

e-ISSN: 2580-2070, p-ISSN: 2527-7650

Table 6. Language Functions

\begin{tabular}{ll}
\hline Language Function & Percentage \\
\hline Giving information & 86.14 \\
\hline Delivering a presentation & 62.04 \\
\hline Giving opinion & 59.63 \\
\hline Responding a complaint & 51.80 \\
\hline Giving instruction & 51.20
\end{tabular}

From five options of the language functions available in the questionnaire, giving information was the most selected one. This result indicated that students were fully aware of and selected what duties they would have in the future. As a matter of fact, the curriculum developer's desired jobs are mostly in the airport and related to service, where giving information to passengers is one of the duties. Delivering a presentation was the next option the students selected. Once again, this fact confirmed that students were aware of the future jobs that required them to deliver a presentation. One of the desired jobs projected by the curriculum developer of this school was the manager in an airline company or airport management industry, in which delivering a presentation is one of the skills commonly required for a manager candidate.

Related to the learning and teaching mode, the academic affairs survey showed that students preferred to study synchronously rather than asynchronously. They admitted that teachers tended to give assignments without giving any explicit instruction and explanation. Therefore, students believed that by having a synchronous online meeting, they could have direct instruction and explanation before confirming any ambiguity regarding the task. Figure 1 shows the students' preferences in running the synchronous meeting based on the survey conducted by the academic affairs. All three choices of the mode were mainly used by the teachers in conducting the synchronous online meeting. 


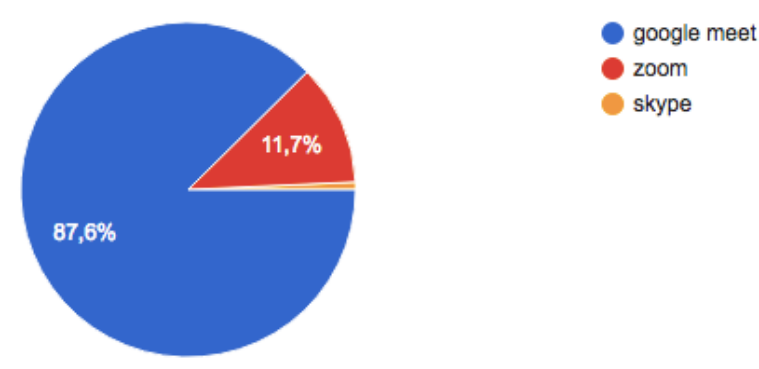

\section{Figure 1. Students' preference in having a synchronous online meeting}

They also mentioned that the biggest challenge in having an online meeting was the internet connection. After the announcement issued by the Ministry of Education stating that all teaching and learning activities should be administered through distance learning, students decided to rejoin with family members in their hometown. In fact, many students came from remote areas, where internet connections remained a struggle. Related to the poor internet connection, massive internet data used impacted financial issues for students. Opting for asynchronous online meeting platforms using fewer internet data should be the best choice.

\section{Topic Preferences}

In relation to the third choice of learning objectives saying that students wanted to improve their Air Transport Management vocabulary, they made choices and selected issues faced by airlines company as the first topic they wanted to learn. The second most selected topic to learn was a marketing communication. The third most selected topic by the students was issues related to human resources management. For detailed information, see Table 7.

Table 7. Topic Preference

\begin{tabular}{cc}
\hline Topic to discuss in the content & Percentage \\
\hline Issues faced by airlines company & 73.49 \\
\hline Marketing communication & 68.67 \\
\hline Issues in human resource management & 57.83 \\
\hline Issues in aviation safety & 53.61 \\
\hline Issues in airport security & 37.34 \\
\hline
\end{tabular}


The student also had their preferences in terms of text type. From the preliminary research, five types of text were mentioned by the students, namely email, product review, report, argumentative essay, and procedure text. From the survey results, most students chose email to be learned. The following text types they wanted to learn were report and procedure text, respectively. This result significantly showed how autonomous they were since they knew what to learn and made choices.

Concerning the autonomous learning level coined by Nunan (as cited in Chitashvili, 2007), in this research, the students were more than aware of their English learning. They could confidently identify their English proficiency level, as the experts and previous researchers have been believing. Moreover, in this study, the results also proved that they could choose their learning objectives, learning preference, and the topic they preferred to study. The researcher ensured that the students participating in this study were at the intervention level since they were involved in selecting learning objectives and learning preferences.

\section{Conclusion and Implication}

From the above presentation of the findings and discussion, the researcher attempts to point out some critical issues. In the initial explanation, the preliminary research showed a positive deed that most teachers have underestimated. The fact that students could make choices and decide their learning objectives and learning preferences was quite surprising since the two previous studies mentioned in the literature review revealed that English learner in Indonesia was far from being autonomous.

As this study's first aim was to find out the learning objectives, students apparently could generate their own learning goals. They mostly wanted to be fluent in English without bothering grammatical aspects. From the result above, it could be concluded that students could decide their priority.

They could adapt their learning objectives by choosing the preferred language functions and topics to discuss in the lesson, giving information and issues faced by airline companies, respectively, as the second aim of this study was to determine the learning preferences. Choosing the online meeting platform was one reason students could decide the learning strategies that suited them well. They were beyond their awareness of being an autonomous learner. They stated where to stand and decide how to run to achieve their learning goals. Hence, to conclude this 
study, the researcher would posit that students in Indonesia generally had a moderate level of learner autonomy, according to what Nunan proposed in Chitashvili (2007).

This research involving only 166 students as respondents, the researcher was fully aware that this research could not represent Indonesian students' situation related to autonomous learning. Therefore, the researcher urged the future researcher to conduct research in an immense scope that can represent Indonesia as a whole. The future researcher may involve several colleges or universities. On the other hand, this research was also lack of validation process for the questionnaire and its result. However, the framework employed to construct the questionnaire was derived from the expert.

Last but not least, this research's impact would be in the hands of teachers, material developers, and school authority. Teachers and material developers can give more materials that embrace the $21^{\text {st }}$-century skill, where autonomous learning is promoted. It is the era for teachers to stop doubting and underestimating students' abilities to be autonomous learners. However, teachers and school authorities must work hand in hand to develop the best-suited curriculum and tasks that help students be more autonomous and independent life-long learners in the long run.

\section{References}

Anza, F., Luthfi, A., \& Saragih, A. (2019). Introduction e-learning in educational sector case study Senior High School in DKI Jakarta. ASEAN Journal of Community, 3(1), 139-162.

Borg, S., \& Al-Busaidi, S. (2012). Learner Autonomy: English Language Teachers' Beliefs and Practices. British Council ELT Research Paper, 1-34.

Brown, J. D. (1995). The elements of language curriculum: A systematic approach to program development. New York: Heinle \& Heinle.

Chitashvili, N. (2007). The Concept of Autonomy in Second Language Learning. Georgian Electronic Scientific Journal: Education Science and Psychology, 11(2), 17-22.

Churiyah, M., Sholikhan, F., \& Sakdiyyah, D. A. (2020, July). Indonesia Education Readiness Conducting Distance Learning in Covid-19 Pandemic Situation. International Journal of Multicultural and Multireligious Understanding, 7(6), 491-507. 
Cirocki, A., Anam, S., \& Retnaningdyah, P. (2019, July). Readiness for Autonomy in English Language Learning: the Case of Indonesia High School Students. Iranian Journal of Language Teaching Research, 7(2), 1-18.

Djalante, R., Lassa, J., Setiamarga, D., Sudjatma, A., Indrawan, M., Haryanto, B., . . Warsilah, H. (2020). Review and analysis of current responses to COVID-19 in Indonesia: Period of January to March 2020. Progress in Disaster Science, 1-9.

Graves, K. (2000). Designing Language Course. Boston: Heinle \& Hainle.

Harmer, J. (2007). The Practice of English Language Teaching. Cambridge: Pearson Longman.

Holec, H. (1981). Autonomy and Foreign Language Learning. New York: Pergamon Press.

Hutchinson, T., \& Waters, A. (1984, April). How communicative is ESP? ELT Journal, 38, 108 -118 .

Koc, N., \& Celik, B. (2014). The Impact of Number of Students per Teacher on Student Achievement. Global Conference on Contemporary Issues in Education (pp. 65-70). Auburn: GLOBE-EDU.

Krashen, S. D. (1982). Principles and practice in second language acquisition. Oxford: Pergamon.

Lengkanawati, N. S. (2017, January). Learner Autonomy in the Indonesian EFL Settings. Indonesian Journal of Applied Linguistics, 6(2), 222-231.

Lie, A. (2009). Education policy and efl curriculum in indonesia: Between the commitment to competence and the quest for higher test scores. TEFLIN, 18(1), 1-14.

Little, D. (1991). Learner Autonomy. Dublin: Authentik Language Learning Resources.

Milton, J., \& Alexiou, T. (2010). Developing a vocabulary size test in Greek as a foreign language. 14th International Conference Advances in Research on Language Acquisition and Teaching. Greek Applied Linguistics Association.

Nation, I. P., \& Macalister, J. (2010). Language Curriculum Design. New York: Routledge.

Nation, I. S. (2006). How Large a Vocabulary Is Needed for Reading and Listening? The Canadian Modern Language Review, 59-82.

Nurweni, A., \& Read, J. (1999). The English vocabulary knowledge of Indonesian University Students. English for Specific Purposes, 18(2), 161-175. 
Richards, J. C. (2001). Curriculum Development in Language Teaching. Liverpool: Cambridge University Press.

Sadeghi, M. (2019). A Shift from Classroom to Distance Learning: Advantages and Limitations. International Journal of Research in English Education, 80-88.

Schmitt, N. (2014). Size an Depth of Vocabulary Knowledge: What the Research Shows. Language Learning, 913-951.

Vedeler, D. (2015). Duration and experience: The temporality of development. In L. M. Simão, D. Guimarães, \& J. Valsiner, Temporality: Culture in the Flow of Human Experience. Tempe: Information Age Publishing.

Waryanto, N. H., \& Stayningrum, W. (2014). E-Learning Readiness in Indonesia: A Case Study in Junior High School Yogyakarta. International Seminar on Innovation in Mathematics and Mathematics Education 1st (pp. 645-654). Yogyakarta: Department of Mathematics Education, Yogyakarta State University.

WHO. (2020, March 22). Newsroom. Retrieved June 2020, from World Health Organization: https://www.who.int/news-room/commentaries/detail/modes-of-transmission-of-viruscausing-covid-19-implications-for-ipc-precaution-recommendations

WHO. (2020). Coronavirus Disease 2019 (Covid-19): Situation Report-94. New York: World Health Organization.

Widodo, H. P. (2015). The development of vocational English materials formal social semiotic perspective: Participatory action research. Adelaide: University of Adelaide, Australia. 


\section{Appendix 1}

Interview Guideline

1. How long have you been studying English?

2. If you are asked to reflect yourself, can you recall what English proficiency level you had when you entered this school?

3. Moreover, on which level are you now?

4. Do you think that the hours of the English meeting in this current English course is adequate?

5. What do you want to achieve as English language learners?

6. What do you expect to get when you finished this English course?

7. What language skills do you wish to learn?

8. Is there any specific topic related to Air Transport Management that you want to learn in this English course? Please mention.

9. What kind of reading text do you want to learn in this English course?

10. In your opinion, what kind of speaking skill or conversation that you will perform in your future occupational setting? 


\section{Appendix 2}

Questionnaire

Part 1

Please fill out the form.

\begin{tabular}{|l|l|}
\hline Name & $:$ \\
\hline Sex & $:$ \\
\hline Age & $:$ \\
\hline
\end{tabular}

Please choose that best suits you.

1. How long have you been studying English?
a. $3-6$ years
b. $6-9$ years
c. $9-12$ years
d. More than 12 years

2. What is your English proficiency level when you entered this college?
a. A1 (Beginner)
b. A2 (Upper Beginner)
c. B1 (Pre-Intermediate)
d. B2 (Intermediate)
e. C1 (Advanced)
f. C2 (Native-like)

3. What is your English proficiency level now?
a. A1 (Beginner)
b. A2 (Upper Beginner)
c. B1 (Pre-Intermediate)
d. B2 (Intermediate)
e. C1 (Advanced)
f. C2 (Native-like) 
Journal of Foreign Language Teaching and Learning

Volume 6, No. 1, January 2021

Available online at: https://journal.umy.ac.id/index.php/FTL/issue/view/720

e-ISSN: 2580-2070, p-ISSN: 2527-7650

Part 2

Please choose three out of five.

1. What is your objective in learning English?

A. To be fluent, whether or not they are grammatically correct

B. Improving listening skill

C. Building up the vocabulary size in the area of Air Transport

Management

D. Improving reading skill

E. Improving skill in writing formal text

2. What speaking skills you think you need in your occupational setting?

A Giving information

B Delivering a presentation

C. Giving opinion

D Responding a complaint

E. Giving instruction

3. What topics do you wish to learn in this English course?

A. Issues faced by airlines company

B. Marketing communication

C. Issues in human resource management

D. Issues in aviation safety

E. Issues in airport security 